\title{
Consumer Propensity to Adopt Illicit Goods: Theory, Methods, and Results
}

\author{
Sergio Enrique Robles-Avila, Arturo Z. Vasquez-Parraga \\ The University of Texas Rio Grande Valley, Edinburg, TX, USA \\ Email: sergio.robles01@utrgv.edu, arturo.vasquez@utrgv.edu
}

How to cite this paper: Robles-Avila, S.E. and Vasquez-Parraga, A.Z. (2018) Consumer Propensity to Adopt Illicit Goods: Theory, Methods, and Results. Theoretical Economics Letters, 8, 292-315.

https://doi.org/10.4236/tel.2018.83021

Received: December 1, 2017

Accepted: February 8, 2018

Published: February 11, 2018

Copyright $\odot 2018$ by authors and Scientific Research Publishing Inc. This work is licensed under the Creative Commons Attribution International License (CC BY 4.0).

http://creativecommons.org/licenses/by/4.0/

\section{cc) (i) Open Access}

\begin{abstract}
The purpose of this study is to examine consumer propensity to adopt illicit goods. The adoption of illicit goods is a worldwide problem that undermines legitimate markets, funds criminal organizations, and harms the most vulnerable in society. International organizations, such as World Economic Forum, have called for the study of the demand of illicit products. Research is crucial to understanding the demand for these products and can contribute to public policy addressing this issue. This research uses two theoretical frameworks: The Theory of Planned Behavior and the Theory of Marketing Ethics. Using the Theory of Planned Behavior, research results suggest that subjective norms influence consumers' propensity to adopt illicit goods. Using the Theory of Marketing Ethics, research on consumers' ethical orientation found that both teleological and deontological orientations influence consumers' ethical judgement and intention. Theoretical and methodological conclusions are derived, and managerial and policy implications are offered.
\end{abstract}

\section{Keywords}

Consumption of Illicit Goods, Consumer Adoption of Illicit Goods, Consumer's Ethical Judgment and Intention to Reward or Punish

\section{Introduction}

The Economist suggested that the consumption of illicit goods is a world-wide, multibillion dollar industry: Drug Trafficking ( $\$ 320$ billion); Counterfeit and Pirated Goods ( $\$ 250$ billion); Human Trafficking ( $\$ 32$ billion); Wildlife Tracking ( $\$ 19$ billion); Oil Trade ( $\$ 11$ billion); Illegal Fishing ( $\$ 10$ billion); Illegal Logging ( $\$ 10$ billion); and Human Organs ( $\$ 0.6$ billion) [1]. In some cases, such as recreational drugs, these illegal goods mentioned are becoming legal. Other figures suggest that the entire illicit goods market totals $\$ 650$ billion USD and illicit final 
flows total \$1.3 trillion USD [2].

The trade of illicit goods is a world-wide problem. Although it is difficult to ascertain a comprehensive list of all illicit goods, the OECD [3] considers the following goods as part of illicit trade: human trafficking, which also includes sex services, goods derived from wildlife, counterfeit goods, narcotics, tobacco products, alcohol, and sports betting. Furthermore, globalization has facilitated the trade of these illicit goods [4]. The scale of this problem is often difficult to assess. This is because much of the trade in illicit goods is secret and illegal in nature. It should be noted, however, that these figures only capture the value of cross-border illicit trade [2]. Indeed, these figures exclude the trade of illicit goods that take place within the countries such as China [4].

Understanding the trade of illicit goods is important because the demand for these goods comes directly from consumers. The trafficking of illicit goods increases economic, environmental, and social risks worldwide. The trade of illicit goods deters financial flows away from the legitimate economy. The trade of goods derived from endangered animals and plants puts excessive stress on already damaged ecosystems. Furthermore, the social consequences of the illicit economy can cause bodily harm and even death [2]. It should also be noted that illicit trade also funds international terrorism. Terrorist groups such as ISIS fund their operations through the trade of illicit goods such as antiquities and stolen oil. Therefore, INTERPOL has recently formed an "illicit markets" sub-crime division to provide law-enforcement agencies worldwide with the necessary experience to confront this problem [4]. Therefore, the appeal to understand the demand of illicit goods in the market leads to the first research question:

RQ1: What is the consumer propensity to adopt illicit goods?

In order to answer this question, the researcher needs to uncover consumer propensity to adopt an illicit good. Apparently, some consumers adopt illicit goods to satisfy a need or desire.

The phenomenon also relates to the ethical orientation of people, that is, how they form ethical judgements and make ethical decisions when obtaining or purchasing illicit goods. Thus, the next research question:

RQ2: How does ethical judgement guide consumers' intention to reward or punish the adoption of illicit goods?

To answer this question, the researcher needs to examine the way these consumers form ethical judgements and make ethical decisions when acquiring illicit goods. This leads to the preliminary assertion in response to Research Question 2: deontological and teleological orientations both influence some consumers' ethical judgement when confronted with the opportunity to adopt an illicit good.

Thus, this study has two purposes. The first purpose of this study is uncovering the propensity to adopt illicit goods. The second purpose of this study is to determine the ethical orientation of these consumers. The rationale behind this study is to better understand the demand behavior of consumers who adopt illi- 
cit goods. The World Economic Forum [2] suggests that influencing public opinion and understanding why consumers buy illicit goods is crucial to addressing this problem because if consumer demand is not changed, demand for illicit goods will continue. Furthermore, this research will also attempt to reveal the ethical judgement consumers use when purchasing or acquiring these illicit goods. This way, the results of this study can contribute to the discussion on how to curb the demand for illicit goods and the "shadow economy". Indeed, the World Economic Forum has stated that illicit trade is not sufficiently researched. This creates a situation where policy makers are not sufficiently aware of its importance and as a consequence, others take advantage of this unfamiliarity to discredit possible initiatives to control illicit trade [5].

Much of the literature that researches the consumption of illicit goods generally focuses on consumer motivations [6]-[13]. Research on the consumption of illicit goods also covers attitudes [14] [15] [16]. The underlying ethical decision-making process behind the adoption of illicit goods, however, has not yet been uncovered. Therefore, this research attempts to fill the gap in the consumer misbehavior research by not only examining consumer propensity to adopt illicit goods, but also by uncovering their ethical decision making when confronted with the opportunity to consume an illicit good.

The remainder of this paper is divided into the following parts: first, the literature review of academic and non-academic sources that describes in detail the nature of illicit goods and their consumption is summarized and discussed. Next, the theoretical framework, hypotheses, methodology, and results are formulated and explained. Lastly, conclusions, managerial and policy implications, limitations, and future research are offered.

\section{Literature Review}

The following literature review examines the definition of an illicit good and its consumption. The definition of an illicit good is crucial to the understanding of the illicit goods trade. There are many goods that are considered illicit and others that are not. This is because the definition of an illicit good may change due to time periods and legal definitions. Therefore, a detailed definition of an illicit good is necessary. Moreover, a brief overview of the literature on the consumption of illicit goods is provided. This review aids in the understanding of consumers' demand of illicit goods.

\subsection{The Illicit Goods Market}

The OECD defines illicit trade as, "an exchange in the control or possession of a good or service that a legislature deems illegal, because of the object of exchange is dangerous or morally repugnant ([3] p.19)". Illicit trade is not concentrated to any region or country. It is a worldwide problem. Every region on earth engages in illicit trade. Therefore, a global response is required [17].

The illicit economy involves the environment, natural resources, violence, po- 
litical instability, cybercrime, human mobility, and corruption at all levels. It can also threaten infrastructure, international trade and investment, supply chains, the retail economy, and banking and capital markets worldwide [17]. Envelope payments, sometimes known cash wages, to workers contributes to the illicit flow of money [18]. Illicit goods such as marijuana, sex services, and alcohol can be legal in some countries, even regions within countries, and illegal in others. Therefore, this research will use the same categories that the OECD uses when they define illicit goods: human trafficking, specifically sex services, wildlife, counterfeit goods, especially counterfeit medicines, narcotics, tobacco, alcohol, and sports betting [3].

It should be noted, however, that social stigma associated with the consumption of illicit goods is rapidly decreasing. Indeed, in many parts of the world, engagement in the illicit economy allows individuals to gain political power, increase economic leverage, or buy legitimacy with the population. Furthermore, there is a complete lack of penalty for those that engage in illicit trade and complicity increases over time. The permissive culture and lack of transparency that results, allows business, governments, and criminal organizations to operate with impunity [17]. What follows is a brief description of the state and nature of illicit goods.

\subsubsection{Human Trafficking, Sex Services}

According to the International Labor Organization, at any given time, 40.3 million people are victims of modern slavery, about 4.8 million in sex slavery. Women and girls are disproportionately affected, accounting for $99 \%$ of the victims in the illicit sex industry [19].

\subsubsection{Wildlife Goods}

Crimes against wildlife, specifically the buying and selling of goods made from endangered species, is now the world's fourth largest crime sector. About 258 billion USD of flora and fauna and other natural resources are stolen annually by criminals. Crimes against the environment include a minimal risk of detection and criminal prosecution as well as high financial payoffs for the perpetrators. The trafficking of wild animals and illegal logging are of specific concern [20].

\subsubsection{Counterfeit Goods}

Counterfeit goods represent a multibillion dollar criminal activity. Criminal groups worldwide have profited from the illicit trade of counterfeited goods. The buying and selling of counterfeit goods is especially dangerous to the world economy due to the intricate links between drug trafficking, money laundering, and corruption. Nonetheless, there is a high tolerance and low penalties for the trafficking of counterfeited goods worldwide. Therefore, this activity is so attractive to organized crime. The most trafficked counterfeited goods are automotive parts, chemicals, pesticides, consumer electronics, electrical parts and components, food and agricultural goods, pharmaceuticals and medicines, tobacco, and other household goods. The counterfeiting of these goods not only damages the licit econo- 
my, these goods also can cause bodily harm and even death to those who knowingly or unknowingly consume counterfeited goods [21].

\subsubsection{Narcotics}

The United Nations considers opium-poppy plants, synthetic opioids, morphine, methadone, cannabis, and coca-leaves as narcotic drugs that pose a significant risk to society. Many of these narcotics have other derivations as well as synthetic alternatives that are bought and sold in the illicit market. Consumption levels, such as levels for opiates, synthetic opioids, have more than tripled in the past 20 years [22]. Although statistics on the size and the scope of the illicit narcotics trade are often heard, the OECD points out that these figures are often unreliable, and a sound measurement is difficult to achieve at the global level [3].

\subsubsection{Illicit Tobacco}

The illicit trade of tobacco goods includes unlicensed production, smuggling, deceitful marketing, and tax dodging. Illicit tobacco goods often are knock-offs of legitimate brands. The illicit trade of tobacco is often linked to money laundering, corruption, and other crimes. The illicit sales of tobacco often take crucial revenues away from governments. These illicit sales also harm legitimate tobacco producers. Some estimates suggest that over 500 billion illicit cigarettes were consumed globally in 2011 [3].

\subsubsection{Illicit Alcohol}

Like illicit tobacco goods, illicit alcohol goods have adverse effects for society. Governments often lose important tax revenues as businesses are deprived of legitimate sales. The World Health Organization (WHO) as well as governments estimate that a significant share of all alcohol consumption is derived from non-commercial sources. One of the most persistent consequences of consuming illicit alcohol is the health risk posed from alcohol poisoning. Poisoning and even death due to unsafe levels of alcohol in the bootleg trade of illicit alcohol goods remains elusive [3].

\subsubsection{Illicit Sports Betting}

Global sports betting has grown exponentially in recent years. Consequently, global sports betting, particularly sport manipulation, often is linked to money laundering and organized crime. Organized crime has been known to penetrate professional leagues to manipulate results. Although manipulated sports betting is a worldwide problem, it is particularly pronounced in Europe. Football is the most seriously affected. The transnational market for sports wagers is estimated to be in the hundreds of billions of dollars [3].

\subsection{Consumption of Illicit Goods}

The adoption of illicit goods falls within the realm of consumer misbehavior. The type of illicit good, purchasing situation, and the price are all significant predictors of willingness to buy. Consumers were most willing to buy an illicit 
good when others are doing the same. On the other hand, consumers were less willing to buy an illicit good if they were alone or with some who was not partaking in the illicit behavior [23]. This is consistent with other research findings. A meaningful relationship exists between adolescents and attributional thinking concerning a peer group's illicit alcohol consumption and conformity, as expressed as intentions to consume alcohol [24].

Some consumers also feel pleasure in response to purchasing a pirated good. For example, research has uncovered that feeling pleasure positively correlates with the intention to adopt and the attitude towards counterfeiting and negatively correlated with the attitude toward the original brand [14]. Consumers' intention to acquire pirated music is influenced by idolatry, or the perceived attachment or veneration of a person or thing, the perceived quality of the good, and the perceived likelihood of punishment [15].

Consumers also experience a range of emotions when consuming illicit goods. For example, consumers are more likely to select non-conspicuous pirated luxury goods after anticipating the potential regret of buying a pirated luxury good. Furthermore, perceived risk also mediates the anticipation of regret. Only some consumers, however, experience the anticipation of regret effect. In this case, only consumers that have an "independent self-view" and are "less conscious of their social face" experience this emotion [25].

\section{Theoretical Framework}

\subsection{Theory of Planned Behavior}

The Theory of Reasoned Action suggests that an individual's behavior is influenced by his or her intentions [26]. In the Theory of Reasoned Action (or TRA), intention is comprised of attitude and subjective norm. Attitude is when an individual feel either favorably or unfavorably about performing a specific behavior. Subjective norms (what individuals think peer would do) illustrate how an individual perceives social pressure towards engaging in a specific behavior. This direct relationship between intention and behavior assumes that the stronger the intention to act on a behavior, the stronger the likelihood that an individual will perform that behavior [27].

The Theory of Planned Behavior (TPB) is a later extension of the TRA. The TPB includes a third element that influences an individual's intention, Perceived Behavioral Control. This new component of the TPB takes into consideration the extent of control in performing a specific behavior, in other words, an individual's perception of the ease to execute the behavior. This component was added to the theory because of the criticism that the original TRA model received for failing to consider an individual's perception of the difficulty of engaging in that behavior. In this research, propensity will take the place of intention. The TRA/TPB framework has been used to explain a wide range of phenomena that explain behavior intention and actual engagement of behavior. For example, the framework has been used to illustrate a marketing manager's perspective on sustaina- 
ble marketing [28], medical tourism [29], and green marketing [30] (see Figure $1)$.

Previous literature suggests that some consumers are motivated to consume an illicit good in a condition where it is legal to engage in its exchange; thus:

H1: Consumers' attitudes to adopt illicit goods have a direct and significant impact on their propensity to adopt illicit goods.

H2: Consumers' subjective norms to adopt illicit goods have a direct and significant impact on consumer propensity to adopt illicit goods.

H3: Perceived behavioral control in the adoption of illicit goods has a direct and significant impact on consumer propensity to adopt illicit goods.

\subsection{Consumer Ethical Judgement and Intention to Reward or Punish the Adoption of Illicit Goods}

To approach consumer ethical orientation, a widely established theory of business ethics is used. The Hunt-Vitell General Theory of Marketing Ethics (HV Theory) is an accepted theory that provides a framework for understanding principal-agent interactions [31] [32] [33]. The HV Theory provides a general theory of ethical decision making that draws on both deontological and teleological ethical evaluations from moral philosophy. The theory explains how an individual might approach an ethical problem and the different alternatives that an individual might take to resolve the problem. The HV Theory provides some illustration how ethical decisions are made.

Deontological evaluations refer to the rightness or the wrongness of an ethical problem. Individuals confronted with an ethical problem will make comparisons among the various alternatives against established norms of the individual's personal values. Teleological evaluations refer to the consequential nature, or how

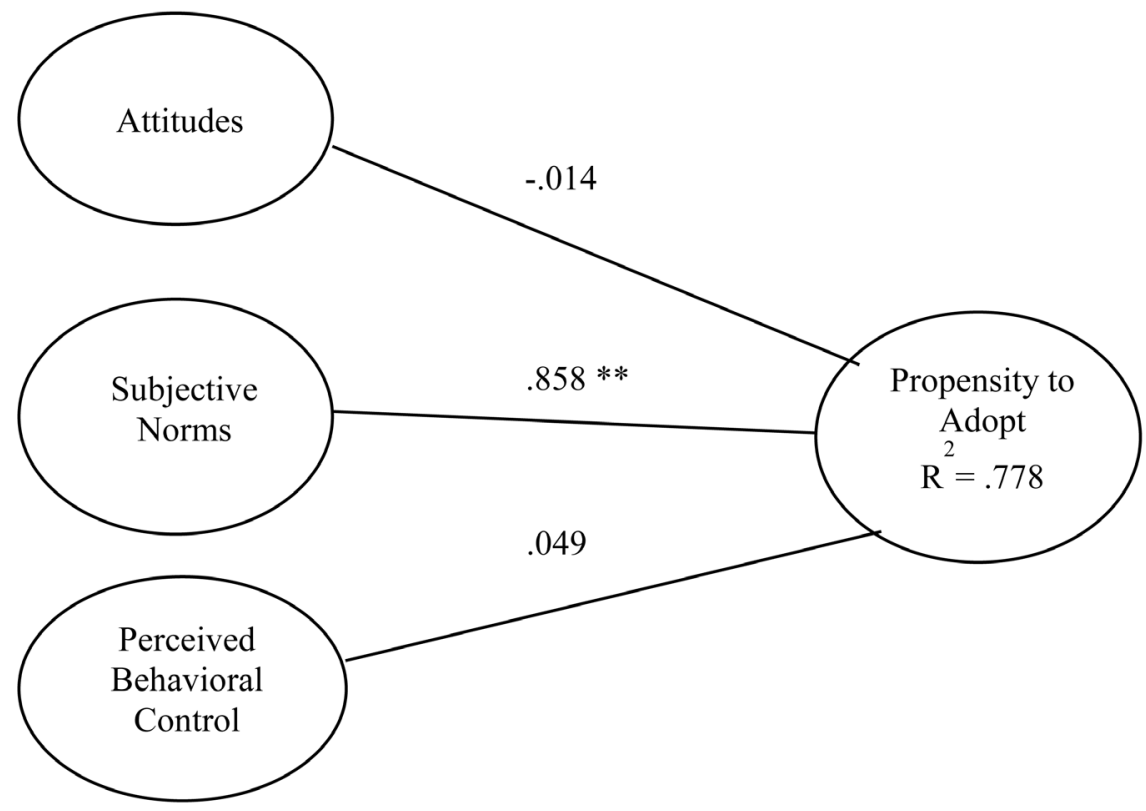

Figure 1. TPB structural model. Note: ${ }^{\star *}$. Significant at 0.0001 level (2-tailed). 
much good or bad, will result from that decision. In other words, a teleological evaluation is considered ethical if the consequences of that decision generate more good than bad as compared to another decision.

As described in the figure below (Figure 2), an individual's ethical judgements are influenced by both deontological and teleological evaluations [34] [35]. First, an individual's perception of that an activity or situation involves an ethical problem leads to a perception of various alternatives that one might take to solve the ethical problem. The ethical problem is then evaluated both deontologically and teleologically. Most individuals are not deontologists or consequentialists [35]. Individuals in most situations evaluate the ethicality of an act based on both deontological and teleological deliberations [34]. The HV Theory has been used to illustrate how ethical decisions are made in the context of marketing-channel relationships [36], consumer ethics [37], and ethics institutionalization in business [38]. This logic suggests that some consumers evaluate deontological and teleological factors when forming ethical judgements and deciding to adopt a good, hence:

H4: Consumers acquiring illicit goods rely on deontological and teleological evaluations in forming their ethical judgements when evaluating the adoption of illicit goods.

H5: Consumers acquiring illicit goods rely on ethical judgements and teleological evaluations to guide their decision to adopt an illicit good.

\section{Methodology}

This research paper will use two methodologies. The first methodology will attempt to uncover consumer propensity to adopt illicit goods. This methodology will be used to test $\mathrm{H} 1, \mathrm{H} 2$, and $\mathrm{H} 3$. The results of these hypotheses tests will reveal the impact of attitudes, subjective norms, and perceived behavioral control on the propensity to adopt an illicit good. The second methodology will be used to test $\mathrm{H} 4$ and $\mathrm{H} 5$. The result of $\mathrm{H} 4$ will reveal if consumers rely on deontological and teleological evaluations when forming ethical judgements when evaluating the adoption of illicit goods. The result of $\mathrm{H} 5$ will reveal if consumers rely on

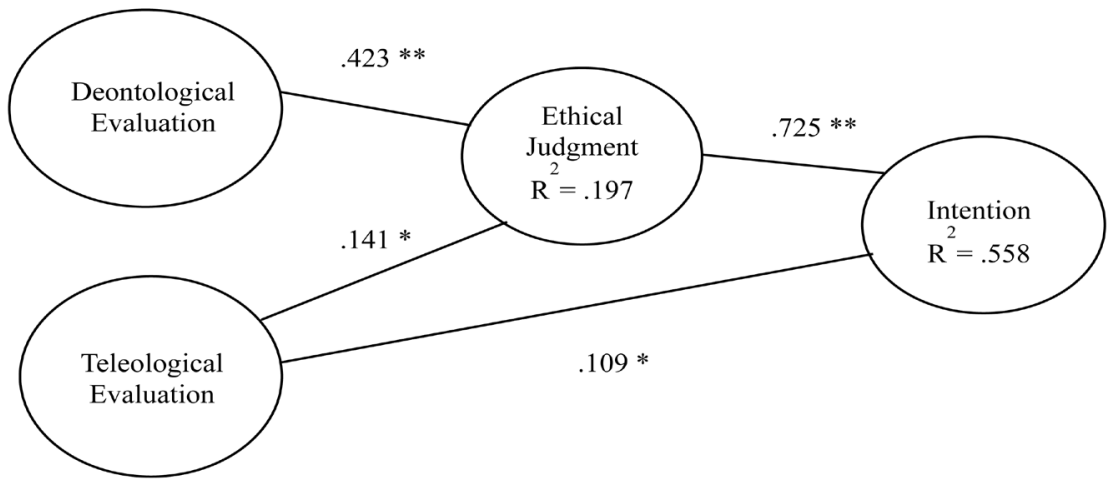

Figure 2. Theory of marketing ethics: core relationships. Note: ${ }^{\star *}$ Significant at 0.0001 level (2-tailed). * Significant at 0.05 level (2-tailed). 
ethical judgements and teleological evaluations that guide their decision to adopt an illicit good.

\subsection{Consumer Propensity to Adopt Illicit Goods}

\subsubsection{Research Design}

The study of the propensity to adopt illicit goods used a self-report survey. Ethics researchers, education researchers, sociologists, as well as criminologists have suggested the difficulty of acquiring accurate data about the sensitive nature of criminal and delinquent behavior, particularly through self-reports [39] [40] [41] [42]. Nonetheless, self-report data remains one of the most popular methods of measuring delinquent behavior [43]. The seriousness of a delinquent act does not alter the use of self-report data [23]. Furthermore, self-report data have been used to examine shoplifting [44], stealing [45], and violence [46].

\subsubsection{Measures}

The measures for attitudes, subjective norms, and perceived behavioral control were employed to predict the propensity to adopt illicit goods. There were five items per construct (see Table 1). For the first construct, attitudes, these five

Table 1. TPB measures.

\begin{tabular}{|c|c|c|}
\hline ITEM & Construct & Source \\
\hline $\begin{array}{l}\text { Some consumers are more likely to adopt illicit goods when } \\
\text { they judge that most consumers do so. }\end{array}$ & ATT1 & [47] \\
\hline $\begin{array}{l}\text { Some consumers are more likely to adopt illicit goods when their friends } \\
\text { recommend the goods. }\end{array}$ & ATT2 & [47] \\
\hline $\begin{array}{l}\text { Some consumers are more likely to adopt illicit goods when they see } \\
\text { celebrities do so. }\end{array}$ & ATT3 & [47] \\
\hline $\begin{array}{l}\text { Some consumers are more likely to adopt illicit goods when } \\
\text { advertisements encourage them to do so. }\end{array}$ & ATT4 & [47] \\
\hline $\begin{array}{l}\text { Some consumers are more likely to adopt illicit goods because they want } \\
\text { to show off. }\end{array}$ & ATT5 & [47] \\
\hline $\begin{array}{l}\text { Most people who are important to me would want me to adopt an illicit } \\
\text { good. }\end{array}$ & SUBN1 & [27] \\
\hline $\begin{array}{l}\text { People whose opinions I value would not have a problem with } \\
\text { me adopting an illicit good. }\end{array}$ & SUBN2 & [27] \\
\hline $\begin{array}{l}\text { Most people who are important to me know that I regularly adopt an } \\
\text { illicit good. }\end{array}$ & SUBN3 & [27] \\
\hline I would post pictures of myself on social media consuming an illicit good. & SUBN4 & Authors' item \\
\hline $\begin{array}{l}\text { I would allow people who are important to me } \\
\text { know that I regularly adopt an illicit good. }\end{array}$ & SUBN5 & [27] [48] \\
\hline Whether or not I adopt an illicit good, is completely up to me. & $\mathrm{PBC1}$ & [48] \\
\hline I am confident that if I wanted to I could adopt an illicit good. & $\mathrm{PBC} 2$ & [48] \\
\hline I have the opportunity to adopt an illicit good. & РBC3 & [49] \\
\hline I have the time to adopt an illicit good. & $\mathrm{PBC} 4$ & [49] \\
\hline I have the resources necessary to adopt an illicit good. & PBC5 & [49] \\
\hline I plan to adopt an illicit good. & PROP1 & [48] \\
\hline I will make an effort to adopt an illicit good. & PROP2 & [48] \\
\hline I intend to adopt an illicit good. & PROP3 & [48] \\
\hline
\end{tabular}


statements were used. These items were modified from past research [47]: 1) Some consumers are more likely to adopt illicit goods when they judge that most consumers do so; 2) Some consumers are more likely to adopt illicit goods when their friends recommend the goods; 3) Some consumers are more likely to adopt illicit goods when advertisements encourage them to do so; 4) Some consumers are more likely to adopt illicit goods when they see celebrities do so; 5) Some consumers are more likely to adopt illicit goods because they want to show off.

Next, subjective norms were measured with five items. These items were modified from past research [27]: 1) Most people who are important to me think I should adopt an illicit good; 2) Most people who are important to me would want me to adopt an illicit good; 3) People's opinions I value would prefer that I adopt an illicit good; 4) I would allow people who are important to me know that I regularly adopt an illicit good; 5) I would post pictures of myself on social media consuming an illicit good.

Perceived behavioral control was measured with five items. These items were modified from past research [48] [49]. 1) I am confident that if I want, I can adopt an illicit good; 2) I have the financial resources to adopt an illicit good; 3) I have the time to adopt an illicit good; 4) I have the opportunity to adopt an illicit good; 5) Whether or not I adopt an illicit good, is completely under my own control.

Lastly, propensity to adopt illicit good used three items. These items were modified from past research [48]. 1) I plan to adopt an illicit good; 2) I will try to adopt an illicit good; 3) I intend to adopt an illicit good.

\subsection{Consumer's Ethical Judgement and Decision to Reward or Punish the Adoption of Illicit Goods}

\subsubsection{Research Design}

The study of the ethical orientations of consumer ethical judgements and decision to reward or punish the adoption of an illicit good used a methodology comparable to that adopted Hunt and Vasquez-Parraga, in which they surveyed managers using four different surveys of two different scenarios. They successfully illustrated how marketing managers evaluated an ethical problem [34]. Conversely, this study used a two-factor design $(2 \times 2)$ to manipulate ethical norms. Four different versions of a scenario were used to determine how consumers form ethical judgements when confronted with an ethical problem, in this case, when confronted with the opportunity to consume an illicit good.

These scenarios combine deontological and teleological evaluations as follows: 1) a deontologically unethical condition with a positive consequence; 2 ) a deontologically unethical condition with a negative consequence; 3 ) a deontologically ethical condition with a positive consequence; and 4) a deontologically ethical condition with a negative consequence. In these four scenarios, an individual is offered an opportunity to adopt pirated goods sold in a neighboring foreign country where legal enforcement is lax (see Appendix A). 


\subsubsection{Measures}

This research used two measures. The first measure was used to evaluate ethical judgements. These measures were evaluated on a 7 -pooint Likert scale $(1=$ very ethical through 7 = very unethical). To evaluate ethical judgement, respondents were asked, "How ethical or unethical do you believe Johnnie's actions were?"

The second measure was used to evaluate respondents' decision. Respondents evaluated a set of rewards and punishments as appropriate or inappropriate. In the questionnaire, respondents were first asked to evaluate the decision by responding to the following question: "Which single alternative do you feel would be most appropriate to take?" These measures followed the research design offered in Vasquez-Parraga [47]. These alternatives were:

1) Give Johnnie the award and the scholarship which is bestowed by the university president.

2) Give Johnnie the scholarship.

3) Give Johnnie strong encouraging feedback.

4) Give Johnnie mild encouraging feedback.

5) Take no action at all.

6) Give Johnnie a written reprimand.

7) Give Johnnie a verbal reprimand.

8) Cancel Johnnie's scholarship.

9) Report Johnnie to the President and cancel the scholarship.

\subsubsection{Sample}

A convenience non-random sample was used for hypotheses testing. A snow-ball technique was used to collect a sample. Students were recruited to distribute the four versions of the questionnaire to their friends, family, and acquaintances on the condition that the respondents were not students and that they were aged 25 years or older. These students were offered extra credit for the number of questionnaires returned. This technique was used to gather respondents from different age groups, ethnic backgrounds, educational backgrounds, and income levels. One-hundred 175 questionnaires were distributed. One-hundred and fifty usable questionnaires were returned.

The average age of the sample was 37 years and $50 \%$ of the sample was male and $50 \%$ of the sample was female. Ethnic background was comprised of the following: $88 \%$ (Hispanic), $4 \%$ (White), and $0.7 \%$ (Black). Thirty-two percent of the sample completed a high school diploma, 34\% completed some college but no degree, $23.3 \%$ completed a bachelor degree, $8.7 \%$ completed a graduate degree, and $2 \%$ failed to provide their educational background. Annual income was reported as follows: $44 \%$ (less than $\$ 30,000), 18.7 \%$ ( $\$ 30,000$ to $\$ 40,000), 8 \%(\$ 40,000$ to $\$ 50,000$ ), $6.7 \%$ ( $\$ 50,000$ to $\$ 60,000$ ), $4.7 \%$ ( $\$ 60,000$ to $\$ 70,000), 16.5 \%$ (more than $\$ 70,000$ ), and $1.3 \%$ (failed to provide their annual income). It should be noted that the sample that measured Consumer Propensity to Adopt Illicit Goods and Consumer's ethical judgement and decision to reward or punish the adoption of illicit goods is the same for both studies. 


\section{Results}

\subsection{Consumption and Knowledge of Illicit Goods}

Respondents in the sample were asked if they were aware of someone in their lives that consumed illicit goods. Respondents were provided a list of 12 different illicit items and were asked to choose if they knew someone that consumed any of the listed items. More than half of the respondents reported that they were aware of the consumption of seven of the 12 different illicit goods. The illicit good most frequently cited was goods made from endangered species (68\%). This was followed by a pet that is an endangered species (66\%), sex services (62\%), goods made from child labor (61\%), food made from an endangered species $(60 \%)$, medicine made from an endangered species (58\%), and recreational drugs (56\%). These results illustrate that the sample is sufficiently aware about the consumption of illicit goods ranging from the consumption of endangered species to the consumption of sex services (see Table 2).

\subsection{Consumer Propensity to Adopt Illicit Goods}

\subsubsection{Factor Analysis and Measurement Validation}

Validity of the measures was assessed using factor loadings and average variance extracted (AVE) (see Table 3). The loadings for attitudes ranged from 0.592 to 0.747 . The loadings for subjective norms ranged from 0.624 to 0.859 . The loadings for perceived behavioral control ranged from 0.574 to 0.847 . Finally, the loadings for propensity ranged from 0.881 to 0.903 . All the loadings scored higher than 0.5 suggesting high internal consistency [50]. These loadings exhibited sufficient convergent validity with loadings above 0.4 .

Average variance extracted (AVE) was calculated for all the constructs. The AVE for attitudes was 0.486. Second, the AVE for subjective norms was 0.572 .

Table 2. Knowledge of the consumption of some illicit good.

\begin{tabular}{cc}
\hline Illicit Good & Knowledge of Consumption \\
\hline Good made from an endangered species & $68 \%$ \\
Pet that is an endangered species & $66 \%$ \\
Sex services & $62 \%$ \\
Good made from child labor & $61 \%$ \\
Food made from endangered species & $60 \%$ \\
Medicine from an endangered species & $58 \%$ \\
Recreational drugs & $56 \%$ \\
Casino gambling & $42 \%$ \\
Controlled medication from Mexico & $25 \%$ \\
Consumer fireworks & $24 \%$ \\
Horse races/sports betting & $22 \%$ \\
Other & $6 \%$ \\
\hline
\end{tabular}


Table 3. Factor analysis results.

\begin{tabular}{|c|c|c|}
\hline Construct & Items & $\begin{array}{c}\text { Factor } \\
\text { Loadings }\end{array}$ \\
\hline & 1. Some consumers are more likely to adopt illicit goods when advertisements encourage them to do so. & 0.747 \\
\hline Attitudes (ATT) & 2. Some consumers are more likely 7to adopt illicit goods when they see celebrities do so. & 0.745 \\
\hline$\alpha=0.732$ & 3. Some consumers are more likely to adopt illicit goods when their friends recommend their goods. & 0.728 \\
\hline \multirow[t]{3}{*}{$\mathrm{AVE}=0.486$} & 4. Some consumers are more likely to adopt illicit goods because they want to show off. & 0.666 \\
\hline & 5. Some consumers are more likely to adopt illicit goods when they judge that most consumers do so. & 0.592 \\
\hline & 1. Most people who are important to me would want me to adopt an illicit good. & 0.859 \\
\hline Subjective Norm (SUBJ) & 2. Most people who are important to me know that I regularly adopt an illicit good. & 0.846 \\
\hline$\alpha=0.803$ & 3. People whose opinions I value would not have a problem with me adopting an illicit good. & 0.736 \\
\hline \multirow[t]{2}{*}{$\mathrm{AVE}=0.572$} & 4. I would post pictures of myself on social media consuming an illicit good. & 0.688 \\
\hline & 5. I would allow people who are important to me know that I regularly adopt an illicit good. & 0.624 \\
\hline \multirow{3}{*}{$\begin{array}{l}\text { Perceived Behavioral Control } \\
\text { (PBC) }\end{array}$} & 1. I have the opportunity to adopt an illicit good. & 0.847 \\
\hline & 2. I have the resources necessary to adopt an illicit good. & 0.814 \\
\hline & 3. I am confident that if I wanted to I could adopt an illicit good. & 0.796 \\
\hline \multirow{2}{*}{$\mathrm{AVE}=0.590$} & 4. I have the time to adopt an illicit good. & 0.780 \\
\hline & 5. Whether or not I adopt an illicit good is completely up to me. & 0.574 \\
\hline Propensity to Adopt(PROP) & 1. I will make an effort to adopt an illicit good. & 0.903 \\
\hline$\alpha=0.875$ & 2. I intend to adopt an illicit good. & 0.899 \\
\hline $\mathrm{AVE}=0.8001$ & 3. I plan to adopt an illicit good. & 0.881 \\
\hline
\end{tabular}

Third, the AVE for perceived behavioral control was 0.590. Last, the AVE for propensity was 0.800 . All AVE calculations scored above 0.50 , suggesting sufficient discriminant validity [50].

The internal consistency of the constructs was evaluated using Cronbach's alpha $(\alpha)$. The Cronbach's alphas for all four constructs scored above the 0.70 threshold recommended [51]. The correlation matrix (Table 4) shows all relationships significant except for attitudes and the propensity to adopt illicit goods.

\subsubsection{Hypotheses Tests}

The three hypotheses testing consumer propensity to adopt illicit goods used regression analysis. H1 posits that consumers' attitudes to adopt illicit goods have a significant impact on their propensity to adopt illicit goods. The effect of attitudes on the propensity to adopt illicit goods is not significant (beta $=-0.014)$ in rejection of $\mathrm{H} 1$.

$\mathrm{H} 2$ posits that consumers' subjective norms to acquire illicit goods have a direct and significant impact on consumers' intention to adopt illicit goods. The effect of subjective norms on propensity to adopt illicit goods is highly significant (beta $=0.858, \mathrm{p}<0.000$ ) in support of $\mathrm{H} 2$.

$\mathrm{H} 3$ posits that perceived behavioral control to acquire illicit goods have a direct and significant impact on consumers' intention to adopt illicit goods. The effect of perceived behavioral control on propensity to adopt illicit goods is not 
Table 4. Correlation coefficients.

\begin{tabular}{ccccc}
\hline & ATT & SUBJ & PBC & PROP \\
\hline ATT & 1 & 0.126 & $0.423^{* *}$ & 0.108 \\
SUBJ & 0.126 & 1 & $0.500^{*}$ & $0.871^{* *}$ \\
PBC & $0.423^{* *}$ & $0.500^{* *}$ & 1 & $0.476^{* *}$ \\
PROP & 0.108 & $0.871^{* *}$ & $0.476^{* *}$ & 1 \\
\hline
\end{tabular}

Note: ${ }^{*}$. Correlation is significant at the 0.01 level. ${ }^{*}$. Correlation is significant at the 0.05 level.

significant (beta $=0.049$ ) in rejection of $\mathrm{H} 3$. The $\mathrm{R}^{2}$ for the model is 0.778 as shown in Figure 1.

\subsection{Consumer's Ethical Judgment and Intention to Reward or Punish the Adoption of Illicit Goods}

\subsubsection{Descriptive Results}

Respondents overwhelmingly supported punishing the individual in the scenario when confronted with an ethical problem, as reported in Table 5. In the first scenario, $48.64 \%$ of the respondents stated that the individual should be punished when committing an unethical act with a positive consequence. On the other hand, $16.21 \%$ of the respondents remained neutral. Finally, 35.13\% of the respondents stated that the individual should be rewarded for committing an unethical act with a positive consequence.

In the second scenario, $72.97 \%$ of the respondents punished the individual when the condition was unethical with a negative consequence. Only $0.08 \%$ of the respondents remained neutral and $18.91 \%$ of the respondents answered that the individual should be rewarded when the condition was unethical with a negative consequence.

In the third scenario, $72.22 \%$ of the respondents rewarded the individual when the condition was ethical and with a positive consequence. Only $0.027 \%$ of the respondents remained neutral and $25 \%$ of the respondents answered that the individual in the scenario should be punished when the condition was ethical with a positive consequence.

In the last scenario, $50 \%$ of the respondents rewarded the individual when the condition was ethical and with a negative consequence. Furthermore, $26.31 \%$ of the respondents remained neutral and $23.68 \%$ of the respondents answered that the individual in the scenario should be punished when the condition was ethical with a negative consequence (see Table 5).

A slight majority of the respondents, $45.94 \%$, answered that the individual acted ethically in the unethical scenario with a positive consequence. On the other hand, 23.24\% answered that the individual acted unethically. Only $10.81 \%$ answered neutrally.

In the second scenario, an overwhelming majority of the respondents, $71.05 \%$, respondents answered that the individual in the scenario acted unethically with a negative consequence. On the other hand, only $26.31 \%$ answered that the individual 
Table 5. Ethical judgement and intention to reward or punish by experimental condition.

\begin{tabular}{ccccc}
$\begin{array}{c}\text { DEON \& TELEO } \\
\text { Conditions }\end{array}$ & $\begin{array}{c}\text { Immoral \& Positive } \\
\text { Consequences }\end{array}$ & $\begin{array}{c}\text { Immoral \& Negative } \\
\text { Consequences }\end{array}$ & $\begin{array}{c}\text { Moral \& Positive } \\
\text { Consequences }\end{array}$ & $\begin{array}{c}\text { Moral \& Negative } \\
\text { Consequences }\end{array}$ \\
\hline INTENTION & & & 72.22 & 50.00 \\
Reward & 35.13 & 0.08 & 0.027 & 26.31 \\
Neutral & 16.21 & 72.97 & 25 & 23.68 \\
Punish & 48.64 & 100 & 100 & 100 \\
Total & 100 & 37 & 36 & 38 \\
n & 37 & & & \\
ETHICAL & & 71.05 & 17.14 & 26.31 \\
JUDGMENT & 43.24 & 2.63 & 0 & 15.78 \\
Unethical & 10.81 & 26.31 & 82.85 & 57.89 \\
Neutral & 45.94 & 100 & 100 & 100 \\
Ethical & 100 & 38 & 35 & 38 \\
Total & 37 & & & \\
$\mathrm{n}^{\mathrm{b}}$ & $17.999(\mathrm{p}<0.901)$ & & & \\
\hline
\end{tabular}

${ }^{\mathrm{a} F}=91.042(\mathrm{p}<0.0001) ;{ }^{\mathrm{b}} \mathrm{F}=17.999(\mathrm{p}<0.0001)$.

acted ethically and $2.63 \%$ were neutral.

In the third scenario, an overwhelming majority of the respondents, $82.85 \%$ answered that the individual acted ethically when the condition was ethical with a positive consequence. On the other hand, $17.14 \%$ answered that the individual acted unethically. No respondents answered neutrally.

In the fourth scenario, $57.89 \%$ of the respondents answered that the individual acted ethically when the condition was ethical with a negative consequence. On the other hand, $26.31 \%$ answered that the individual acted unethically and only $15.78 \%$ were neutral. The correlation matrix (Table 6) shows all relationships significant.

\subsubsection{Hypothesis Tests}

H4 posited that consumers adopting illicit goods rely on deontological and teleological evaluations in forming their ethical judgements when evaluating the adoption of illicit goods. The betas showing the effects of both evaluations are significant (beta $=0.423$ and 0.141 , respectively) though at different levels of significance. The $\mathrm{R}^{2}$ for both effects is 0.197 as shown in Figure 2 .

H5 posited that consumers adopting illicit goods rely on ethical judgments and teleological evaluations when making a decision to either reward or punish the adoption of illicit goods. The betas showing the effects of both evaluations are significant (beta $=0.725$ and 0.109 , respectively) though at different levels of significance. The $\mathrm{R}^{2}$ for both effects is 0.558 as shown in Figure 2. 
Table 6. Correlation coefficients.

\begin{tabular}{ccccc}
\hline & INTENTION & DEON & TELEO & ETHICAL JUDG \\
\hline INTENTION & 1 & $388^{* *}$ & $0.199^{*}$ & $0.739^{* *}$ \\
DEO & $0.388^{* *}$ & 1 & 0.000 & $0.421^{* *}$ \\
TELEO & $0.199^{*}$ & 0.000 & 1 & 0.135 \\
ETHICAL JUDG & $0.739^{* *}$ & $0.421^{* *}$ & 0.135 & 1 \\
\hline
\end{tabular}

Note: ${ }^{* *}$. Correlation is significant at the 0.001 level. ${ }^{*}$. Correlation is significant at the 0.05 level.

\section{Discussion}

\subsection{Consumer Propensity to Adopt Illicit Goods}

This research revealed that subjective norms significantly impact consumer propensity to adopt an illicit good. Consumers evaluate the favorability or unfavourability of a behavior, in this case, the adoption of an illicit good influences consumers. This is important because subjective norms measure how social pressure can motivate a behavior that an individual might engage in. In other words, consumers may be less willing to adopt an illicit good when they are alone, than when other consumers are present, adopting the same illicit good. This is consistent with past research [23]. This is an important revelation because as the proliferation of illicit trade increases, consumers will be increasingly exposed to the adoption of these goods.

\subsection{Consumer's Ethical Judgment and Intention to Reward or Punish the Adoption of Illicit Goods}

This research also shows that consumers rely primarily on their perception of the rightness or wrongness of an action, that is, through deontological evaluation. When consumers assessed the morality of a problem, in this case, consuming a pirated good, they revealed that they primarily evaluated the morality of consuming an illicit good rather than the consequences of consuming an illicit good. This is an interesting observation because in many cases, it is very difficult to punish consumers who consume illicit goods, especially when the value of the illicit good is minimal. Many consumers face little or no consequences when adopting illicit goods, such as pirated music or movies. Furthermore, it appears that the merchant is often held accountable and punished when caught selling an illicit good.

The lack of consequences may suggest why the respondents primarily rely on deontological factors when evaluating the consumption of an illicit product. Indeed, an interesting finding of this research is that the lack of consequences that consumers encounter when adopting an illicit product illustrates why teleological factors have less significance, or are secondary, when consumers evaluate the consumption of an illicit good.

\section{Conclusions}

The adoption of illicit goods is a worldwide problem. As already illustrated in 
this research, the trade of illicit goods contributes to the destruction of the market by diverting profits from legitimate businesses and reducing tax revenue for governments. Furthermore, the trade in illicit goods is linked to other illicit activities such as money laundering, international criminality, corruption, social destabilization, and even international terrorism. Therefore, uncovering the propensity and ethical judgement of consumers that adopt illicit goods is crucial to reversing this worldwide problem. This is because the demand of these goods comes from the consumer [2].

This research contributes to the literature in two important ways: First, it illustrates how subjective norms impact consumer propensity to adopt an illicit good. This is important because international institutions, such as the World Economic Forum [2], the OECD [52], and others, have addressed the global illicit economy and have called for deeper understanding of consumer demand to adopt illicit goods. Second, this research illustrates how deontological factors overwhelmingly impacted consumer ethical judgements to consume illicit goods. The results of this study can help contribute to the debate and to the discussion surrounding the illicit goods trade by providing sufficient scientific and empirical based arguments that can guide managerial and policy implications.

\section{Managerial and Policy Implications}

There are managerial and policy implications. First, consumers need to be educated about the direct and indirect consequences of consuming a wide range of illicit goods. For example, consumers need understand that consuming illicit goods can destroy the lives of vulnerable people, especially those in the sex trade. The consumption of illicit goods also can destroy fragile ecosystems putting the lives of everyone at risk. Furthermore, the consumption of illicit goods diverts crucial resources away from legitimate businesses and governments that, in turn, threaten their stability and the wellbeing of the consumer. In most cases, these illicit flows also launder money and find their way to criminal and terrorist organizations worldwide. The education of consumers on the consequences of purchasing illicit goods needs to be done in a way that can change subjective norms. Indeed, by changing subjective norms, consumers can put pressure on other consumers not to partake in the trade of illicit goods.

This is an important implication because consumers have revealed that they consider what their peers think about their consumption habits, in this case, the adoption of an illicit good. What is worrying, however, is that the trade of illicit good, especially sex services, wildlife goods, counterfeit goods, narcotics, illicit tobacco, illicit alcohol, and sports betting, is increasing. Managers and policy makers should understand that when the consumption of these illicit goods increases, especially through globalization, the stigma of buying these goods decreases [52]. Therefore, the continued adoption of illicit goods will have negative outcomes for both buyers and sellers of illicit goods, especially vulnerable stakeholders in the market such as women, the poor, and the uneducated. 
Governments, law enforcement, and businesses also need to harmonize their definition of an illicit good. In many cases, the legality of an illicit good can change from place to place or even from time to time. Some governments have suggested that legalizing some illicit goods, such as gambling, sex services, and narcotics can eliminate the criminal element of its trade. Even so, these goods still retain their illicit nature. In this case, the stakeholders in the market need emphasize the morality of the consumption of these goods. This is a crucial finding because the results of this research suggest that consumers primarily use deontological factors when confronting a moral problem. In this case, the adoption of an illicit good. Therefore, managers and policy makers need to emphasize the ethical consequences of consuming sex services, goods derived from endangered species, narcotics, pirated goods, and gambling. Indeed, this might be more effective than emphasizing the consequential nature, or the teleological factors when engaging in the illicit economy. Thus, seeking to punish consumers who consume illicit goods may be counterproductive or ineffective when the results of this study illustrate that teleological considerations are secondary.

\section{Limitations of the Study}

There are two important limitations to this study. The first limitation is the broad use of "illicit goods". The range of illicit goods is very extensive. What one consumer may consider illicit may not be illicit for another. Many goods that have little in common could be considered "illicit". The nature and intensity of certain illicit goods may be more pronounced with one when compared to the other. It could be possible that for some consumers, purchasing an illicit good such as an exotic pet would not be controversial but purchasing sex services could be detestable.

The second limitation is the sample. Almost $90 \%$ of the sample was Hispanic and from the US-Mexico border region. Opportunities to adopt pirated or illicit goods in Mexico may be easier for Mexican consumers than for consumers that live in other countries or places where no international border is present. The overwhelming Hispanic sample that lives along the US-Mexico border may introduce some bias into the empirical results.

\section{Future Research}

There are two suggestions for future research. The first suggestion would be to attempt to study producers in the illicit economy rather than the consumers. Although consumers generate the demand for illicit goods, producers also supply these goods. A comparison between the results of the consumers and the producers could give new insights into the problem of the illicit economy.

Second, although the sample of this study was more than adequate $(n=150)$, most of the respondents were Hispanic/Latino (non-White) and from South Texas. A sample outside of the South Texas area could provide more results that could provide insights into the geographical and ethic differences about the adoption of illicit goods. 


\section{References}

[1] The Economist (2013) Daily Chart: Illegal Markets.

[2] World Economic Forum (2012) Global Agenda Council on Illicit Trade. World Economic Forum, Vienna.

[3] OECD (2016) Illicit Trade: Converging Criminal Networks, OECD Reviews of Risk Management Policies. OECD Publishing, Paris.

[4] World Economic Forum (2015) State of the Illicit Economy Briefing Papers. World Economic Forum, Vienna.

[5] World Economic Forum (2009) Illicit Trade Annex 1: The Main Types of Illicit Trade. World Economic Forum, Vienna.

[6] Gao, Y. and Clark, S.G. (2014) Elephant Ivory Trade in China: Trends and Drivers. Biological Conservation, 180, 23-30. https://doi.org/10.1016/j.biocon.2014.09.020

[7] Ross, M.W., Mattison, A.M. and Franklin Jr., D.R. (2003) Club Drugs and Sex on Drugs Are Associated with Different Motivations for Gay Circuit Party Attendance in Men. Substance Use \& Misuse, 38, 1173-1183. https://doi.org/10.1081/JA-120017657

[8] Bonn-Miller, M.O., Zvolensky, M.J. and Bernstein, A. (2007) Marijuana Use Motives: Concurrent Relations to Frequency of Past 30-Day Use and Anxiety Sensitivity among Young Adult Marijuana Smokers. Addictive Behaviors, 32, 49-62. https://doi.org/10.1016/j.addbeh.2006.03.018

[9] Wilcox, K., Kim, H.M. and Sen, S. (2009) Why Do Consumers Buy Counterfeit Luxury Brands? Journal of Marketing Research, 46, 247-259. https://doi.org/10.1509/jmkr.46.2.247

[10] Alfadl, A.A., Ibrahim, M.I.M. and Hassali, M.A. (2012) Consumer Behaviour towards Counterfeit Drugs in a Developing Country. Journal of Pharmaceutical Health Services Research, 3, 165-172. https://doi.org/10.1111/j.1759-8893.2012.00095.x

[11] Shanahan, K.J. and Hyman, M.R. (2010) Motivators and Enablers of Scouring: A Study of Online Piracy in the US and UK. Journal of Business Research, 63, 1095-1102. https://doi.org/10.1016/j.jbusres.2009.02.026

[12] Pellegrini, B., Fry, T.R. and Aitken, C.K. (2011) Understanding the Motivations of Contraband Tobacco Smokers. Drugs. Education, Prevention and Policy, 18, 387-392. https://doi.org/10.3109/09687637.2011.562935

[13] Fang, X. and Mowen, J.C. (2009) Examining the Trait and Functional Motive Antecedents of Four Gambling Activities: Slot Machines, Skilled Card Games, Sports Betting, and Promotional Games. Journal of Consumer Marketing, 26, 121-131. https://doi.org/10.1108/07363760910940483

[14] Marticotte, F. and Arcand, M. (2017) Schadenfreude, Attitude and the Purchase Intentions of a Counterfeit Luxury Brand. Journal of Business Research, 77, 175-183. https://doi.org/10.1016/j.jbusres.2016.12.010

[15] Dilmperi, A., King, T. and Dennis, C. (2017) Toward a Framework for Identifying Attitudes and Intentions to Music Acquisition from Legal and Illegal Channels. Psychology \& Marketing, 34, 428-447. https://doi.org/10.1002/mar.20998

[16] Carpenter, J.M. and Edwards, K.E. (2013) US Consumer Attitudes toward Counterfeit Fashion Products. Journal of Textile \& Apparel Technology \& Management, 8, $1-16$.

[17] World Economic Forum (2017) Mapping Global Transformations. https://www.weforum.org/about/transformation-maps 
[18] Williams, C. (2015) Evaluating the Prevalence of the Undeclared Economy in Central and Eastern Europe: An Institutional Asymmetry Perspective. European Journal of Industrial Relations, 21, 1-18.

[19] ILO (2017) Global Estimates of Modern Slavery. International Labor Organization and Walk Free Foundation, Geneva.

[20] World Customs Organization (2017) Illicit Trade Report: 2016. World Customs Organizations Publishers, Brussels.

[21] UNODC (2017) The Illicit Trafficking of Counterfeit Goods and Transnational Organized Crime. The United Nations Office on Drugs and Crime, Vienna.

[22] INCB (2015) Narcotic Drugs: Estimated World Requirements for 2016. United Nations, Vienna.

[23] Albers-Miller, N. (1999) Consumer Misbehavior: Why People Buy Illicit Goods. Journal of Consumer Marketing, 16, 273-287. https://doi.org/10.1108/07363769910271504

[24] Rose, R., Bearden, W. and Teel, J. (1992) An Attributional Analysis of Resistance to Group Pressure regarding Illicit Drug and Alcohol Consumption. Journal of Consumer Research, 19, 1-13. https://doi.org/10.1086/209281

[25] Chen, J., Teng, L., Liu, S. and Zhu, H. (2015) Anticipating Regret and Consumers' Preferences for Counterfeit Luxury Goods. Journal of Business Research, 68, 507-515. https://doi.org/10.1016/j.jbusres.2014.09.012

[26] Fishbein, M. and Ajzen, I. (1975) Belief, Attitude, Intention and Behavior: An Introduction to Theory and Research. Addison-Wesley, Reading.

[27] Ajzen, I. (1991) The Theory of Planned Behavior. Organizational Behavior and Human Decision Processes, 50, 179-211. https://doi.org/10.1016/0749-5978(91)90020-T

[28] Ferdous, A.S. (2010) Applying the Theory of Planned Behavior to Explain Marketing Managers' Perspectives on Sustainable Marketing. Journal of International Consumer Marketing, 22, 313-325. https://doi.org/10.1080/08961530.2010.505883

[29] Ramamonjiarivelo, Z., Martin, D.S. and Martin, W.S. (2015) The Determinants of Medical Tourism Intentions: Applying the Theory of Planned Behavior. Health Marketing Quarterly, 32, 165-179. https://doi.org/10.1080/07359683.2015.1033934

[30] Kalafatis, S.P., Pollard, M., East, R. and Tsogas, M.H. (1999) Green Marketing and Ajzen's Theory of Planned Behaviour: A Cross-Market Examination. Journal of Consumer Marketing, 16, 441-460. https://doi.org/10.1108/07363769910289550

[31] Hunt, S. and Vitell, S. (1986) A General Theory of Marketing Ethics. Journal of Macromarketing, 6, 5-16. https://doi.org/10.1177/027614678600600103

[32] Hunt, S. and Vitell, S. (1992) The General Theory of Marketing Ethics: Retrospective and Revision. In: Smith, N.C. and Quelch, J.A., Eds., Ethics in Marketing, Irwin, Homewood, 775-784.

[33] Hunt, S. and Vitell, S. (2006) The General Theory of Marketing Ethics: A Revision and Three Questions. Journal of Macromarketing, 26, 143-153. https://doi.org/10.1177/0276146706290923

[34] Hunt, S. and Vasquez-Parraga, A. (1993) Organizational Consequences, Marketing Ethics, and Salesforce Supervision. Journal of Marketing Research, 30, 78-90. https://doi.org/10.2307/3172515

[35] Vitell, S. and Hunt, S. (1990) The General Theory of Marketing Ethics: A Partial Test of the Model. Research in Marketing, 10, 237-265.

[36] Vermillion, L., Lassar, W. and Windsor, R. (2002) The Hunt-Vitell General Theory 
of Marketing Ethics: Can It Enhance Our Understanding of Principal-Agent Relationships in Channels of Distribution? Journal of Business Ethics, 41, 267-285. https://doi.org/10.1023/A:1021284922440

[37] Vitell, S., Singhapakdi, A. and Thomas, J. (2001) Consumer Ethics: An Application and Empirical Testing of the Hunt-Vitell Theory of Ethics. Journal of Consumer Marketing, 18, 153-178. https://doi.org/10.1108/07363760110386018

[38] Vitell, S. and Singhapakdi, A. (2008) Consumer Ethics: An Application and Empirical Testing of the Hunt-Vitell Theory of Ethics. Journal of Business Ethics, 81, 343-353. https://doi.org/10.1007/s10551-007-9498-x

[39] Al-Jabri, I. and Abdul-Gader, A. (1997) Software Copyright Infringements: An Exploratory Study of the Effects of Individual and Peer Beliefs. Omega International Journal of Management Science, 3, 335-344. https://doi.org/10.1016/S0305-0483(96)00053-9

[40] Brenner, P. and DeLamater, J. (2014) Social Desirability Bias in Self-Reports of Physical Activity: Is an Exercise Identity the Culprit? Social Indicators Research, 117, 489-504. https://doi.org/10.1007/s11205-013-0359-y

[41] Miller, A. (2012) Investigating Social Desirability Bias in Student Self-Report Surveys. Educational Research Quarterly, 36, 30-47.

[42] Thornberry, T. and Krohn, M. (2000) The Self-Report Method for Measuring Delinquency and Crime. Measurement and Analysis of Crime and Justice, 4, 33-83.

[43] Farrington, D.P. (1973) Self-Reports of Deviant Behaviour: Predictive and Stable? Journal of Criminal Law and Criminology, 64, 99-110. https://doi.org/10.2307/1142661

[44] Tonglet, M. (2002) Consumer Misbehavior: An Exploratory Study of Shop Lifting. Journal of Consumer Behavior, 9, 336-354. https://doi.org/10.1002/cb.79

[45] Grant, J., Potenza, M., Krishnan-Sarin, S., Cavallo, D. and Desai, R. (2011) Stealing among High School Students: Prevalence and Clinical Correlates. Journal of the American Academy of Psychiatry and the Law, 239, 44-52.

[46] Ambuel, B., Butler, D., Hamberger, K., Lawrence, S. and Guse, C. (2003) Female and Male Medical Students' Exposure to Violence: Impact on Wellbeing and Perceived Capacity to Helped Battered Women. Journal of Comparative Family Studies, 34, 113-135.

[47] Vasquez-Parraga, A. (2016) Consumer Attitudes on Acquiring Goods Derived from Endangered Species. Working Paper, University of Texas Rio Grande Valley, Rio Grande City.

[48] Ajzen, I. and Fishbein, M. (1980) Understanding Attitudes and Predicting Social Behavior. Prentice-Hall, Englewood Cliffs.

[49] Suki, N. and Suki, N. (2015) Consumers' Environmental Behavior towards Staying at a Green Hotel: Moderation of Green Hotel Knowledge. Management of Environmental Quality: An International Journal, 26, 103-117. https://doi.org/10.1108/MEQ-02-2014-0023

[50] Hair, J.F., Black, W.C., Babin, B.J. and Anderson, R.E. (2010) Multivariate Data Analysis. 7th Edition, Prentice Hall, Upper Saddle River.

[51] Nunnally, J.C. (1979) Psychometric Theory. McGraw-Hill, New York.

[52] OECD/EUIPO (2016) Trade in Counterfeit and Pirated Goods: Mapping the Economic Impact. OECD Publishing, Paris. 


\section{Appendix A: Treatment Scenarios}

\section{Scenario 1: Deontologically Immoral Condition with Positive Consequences}

Johnnie, a graduate student, enjoys watching movies. He was recently elected student government president by his peers. Every Friday, Johnnie invites his fellow student government officers as well as other students to his home to watch the latest movies on his home entertainment system. Because Johnny receives a rather low stipend, it was getting ever more expensive for him to purchase movies. One day, Joe, a fellow graduate student, told Johnnie that he could buy the same movies across the border in Reynosa, Mexico at a cheaper price. Johnnie then asked Joe, “Can't I get into trouble for buying these pirated movies?" Joe replied, "Only if you get caught. Make sure to buy only a few at a time and hide them in your jacket. No one will suspect a thing when you return to the USA." Johnnie was hesitant at first about buying pirated movies in Reynosa, but then he realized how much he enjoyed having all the popular students over to his home to watch movies. He reasoned that no one would know that he purchased these pirated movies in Reynosa because he would just hide them in his jacket, thus the chances of getting caught would be slim. Johnnie decided to purchase pirated movies in Reynosa every other week, and he hid them in his jacket to avoid getting caught. One day, the president of the university summoned Johnnie to his office and informed Johnnie that he had been selected for the "Outstanding Student Government Officer Award" for his efforts to build a welcoming community on campus. The president was most impressed that Johnnie invited his fellow student government officers as well as students to his home on Fridays to watch movies at his expense. Part of the award includes a $\$ 1,000$ scholarship.

\section{Scenario 2: Deontologically Immoral Condition with Negative Consequences}

Johnnie, a graduate student, enjoys watching movies. He was recently elected student government president by his peers. Every Friday, Johnnie invites his fellow student government officers as well as other students to his home to watch the latest movies on his home entertainment system. Because Johnnie receives a rather low stipend, it was getting ever more expensive for him to purchase movies. One day, Joe, a fellow graduate student, told Johnnie that he could buy the same movies across the border in Reynosa, Mexico at a cheaper price. Johnnie then asked Joe, “Can't I get into trouble for buying these pirated movies?" Joe replied, "Only if you get caught. Make sure to buy only a few at a time and hide them in your jacket. No one will suspect a thing when you return to the USA." Johnnie was hesitant at first about buying pirated movies in Reynosa, but then he realized how much he enjoyed having all of the popular students over to his home to watch movies. He reasoned that no one would know that he purchased pirated movies in Reynosa because he would just hide them in his jacket, and the chances of getting caught would be slim. Johnnie decided to purchase pirated 
movies in Reynosa every other week, and he hid them in his jacket to avoid getting caught. One day, the president of the university summoned Johnnie to his office to inform Johnnie that he had been selected for the "Outstanding Student Government Officer Award" for his efforts to build a welcoming community on campus. The president was most impressed that Johnnie invited his fellow student government officers as well as students to his home on Fridays to watch movies at his expense. Part of the award includes a $\$ 1000$ scholarship. Hollie, the student government treasurer, found out through rumors what Johnnie was doing. Remembering the university's code of ethics, she turned Johnnie in. When the president found out what Johnnie was doing, he canceled the award, rescinded the scholarship, and recommended Johnnie for suspension from the student government.

\section{Scenario 3: Deontologically Moral Condition with Positive Consequences}

Johnnie, a graduate student, enjoys watching movies. He was recently elected student government president by his peers. Every Friday, Johnnie invites his fellow student government officers as well as other students to his home to watch the latest movies on his home entertainment system. Because Johnnie receives a rather low stipend, it was getting ever more expensive for him to purchase movies. One day, Joe, a fellow graduate student, told Johnnie that he could buy the same movies across the border in Reynosa, Mexico at a cheaper price. Johnnie then asked Joe, "Can't I get into trouble for buying these pirated movies?" Joe replied, "Only if you get caught. Make sure to buy only a few at a time and hide them in your jacket. No one will suspect a thing when you return to the USA." Johnnie was hesitant at first about buying pirated movies in Reynosa, but then he realized that he was elected student government president by his peers. $\mathrm{He}$ wanted to set a good example for the entire campus and did not want to disappoint his parents and professors. Johnnie replied that he would continue to buy the movies "the right way" and that he'd find a way to pay for them. Through rumors, the president of the university found out that Johnnie stood up for ethical principles by refusing to buy pirated movies in Reynosa. One day, the president of the university summoned Johnnie to his office to inform him that he had been selected for the "Outstanding Student Government Officer Award" for his efforts to build a welcoming community on campus. The president was most impressed that Johnnie invited his fellow graduate student officers as well as students to his home to watch movies at his expense. Part of the award includes a $\$ 1000$ scholarship.

\section{Scenario 4: Deontologically Moral Condition with Negative Consequences}

Johnnie, a graduate student, enjoys watching movies. He was recently elected student government president by his peers. Every Friday, Johnnie invites his fellow student government officers as well as other students to his home to watch 
the latest movies on his home entertainment system. Because Johnnie receives a rather low stipend, it was getting ever more expensive for him to purchase movies. One day, Joe, a fellow graduate student, told Johnnie that he could buy the same movies across the border in Reynosa, Mexico at a cheaper price. Johnnie then asked Joe, "Can't I get into trouble for buying these pirated movies?" Joe replied, "Only if you get caught. Make sure to buy only a few at a time and hide them in your jacket. No one will suspect a thing when you return to the USA." Johnnie was hesitant at first about buying pirated movies in Reynosa, but then he realized that he was elected student government president by his peers. $\mathrm{He}$ wanted to set a good example for the entire campus and did not want to disappoint his parents and professors. Johnnie replied that he would continue to buy the movies "the right way" and that he'd find a way to pay for them. Frustrated, Joe told Hollie, the student government treasurer that she should host movie night at her home. He told her that she could buy the movies more inexpensively in Reynosa than she could at home. Hollie jumped at the opportunity to host movie night. Eventually students stopped visiting Johnnie's home and visited Hollie's home instead. One day, the president of the university summoned Johnnie to his office to inform him that he had selected Hollie for the "Outstanding Student Government Officer Award” for her efforts to build a welcoming community on campus. The president was most impressed that Hollie invited her fellow graduate student officers as well as students to her home to watch movies at her expense. The president told Johnnie that he wanted him to have the honor of informing Hollie of her award, and that she would be also be awarded a $\$ 1000$ scholarship. 